\title{
THE GROUND OF JUSTIFICATYON
}

(The second of a series in which members set out the questions which give rise to their present researches)

Vincent Taylor makes the observation about justification that "The central place of the doctrine in St. Paul's itheology, and the crucial importance assigned to it at the Reformation, are in striking contrast with the virtual neglect of this teaching in current theological literature and in modern preaching" (Forgiveriess and Reconciliation pp. 72f.) He continues: "What is required in modern teaching, and few things are needed more, is a renewed emphasis on the truths for which justification stands. ...So anxious have we been to exclude legal ideas from our thoughts of God that we have compromised the ethical foundations of cur theology. We have created God in our own image and likeness ." (pp. 79-8o). There is little reason to believe that the situation has radically changed for the better since $194 \mathrm{I}$, when these words were written.

Last century saw the production of a fair number of works on the subject of justification, but literature has been very scanty so far this century. In any case the emphasis today seems to be on what man must do for salvation rather than on what God has already done in Christ for sinners. There is some discussion about man's exercise of faith, but less interest in Christ as the object of faith.

In 1867 James Buchanan wrote: "The great cardinal question on the subject of Justification, - and that on the right settlement of which the determination of every other mainly depends,-relates to its immediate ground; and amounts in substance to this, - What is the righteousness, on account of which a sinner is forgiven and accepted as righteous in the sight of God? or, What is the righteousness to which God has regard in bestowing and on which a sinner should rely for obtaining, the forgiveness of his sins, and a title to eternal life? or in yet another form,- - whether the righteousness which is revealed as the ground of our justification be the vicarious righteousness of Christ imputed, or our cwn personal righteousness, infused and inherent" (The Doctrine of justification p. 239).

Even Newman could write: "The purpose of this Appendix is to show that the cardinal question to be considered by Catholics and Protestants in their controversy about Justification is, What is its formal cause? (footnote p. 343) ... To determine what is the formal cause of our justification or what it is which under the Christian covenant constitutes us just in God's sight, or what it is in us in which our justification consists, or what it is immediately upon which we receive God's justification, is as important an undertaking as any one in the controversy, ... The question may be thrown into the following more practical shape: What is it which God will look on at the last day and accept us in. What will be the immediate antecedent in our souls to the words, 'Come, ye blessed'" (Lectures on the Doctrine of Justification, 4th edition, 1885 , p. 346 ).

In the seventeenth century John Owen held the same view about the importance of the ground of justification: "Herein lies the substance of the whole controversy about our justification before God, upon the determination and stating whereof the determination of all other incident questions doth depend.

"This, therefore, is that which herein I affirm:-The righteousness of Christ (in his obedience and suffering for us) imputed unto believers, as they are united to $\mathrm{Him}$ by $\mathrm{His}$ Spirit, is that righteousness whereon they are justified before God, on the account whereof their sins are pardoned, and a right is granted them unto the heavenly inheritance. ...

"This is the shield of truth in the whole cause of justification; which, whilst it is preserved safe, we need not trouble ourselves about the differences that are among learned ment about the proper stating and declaration of some lesser concernments of it. This is the refuge, the only refuge, of distressed consciences, wherein they may find rest and peace" (The Doctrine of Justification by Faith; Works, edited by W. H. Goold, Vol. V. 1850. p. 208).

But today the ground of justification is largely ignored. Many writers use the term 'ground' more loosely for one of the causes of justification. For example, Dodd can talk of "Paul's teaching, 'that God justifies the ungodly on the ground of faith" (Romans, Moffatt New Testament Commentary, p. 92). Frequently a quality in man seems to be made the ground of justification. 
Thus Dodd writes: "God sees in us that which in Christ we are becoming, and acquits us" (p. 143). Does not such a 'statement tend to support the error of the Roman Catholic Church on this point? Is it possible consistently to hold such a view together with that of the Reformers? "The Reformers taught that, when God pardoned and accepted any sinner, the ground or basis of the divine act that to which God had directly and immediately a respect or regard in performing it, or in passing a virtual sentence cancelling that man's sins, and admitting him into the enjoyment of His favour,-was this, that the righteousness of Christ was his through his union to Christ; that being his in this way, it was in consequence imputed to him, or put down to his account, just as if it were truly and properly his own; and that this righteousness, being in itself fully satisfactory and meritotious, formed an adequate ground on which sins might be forgiven and his person 'accepted" (W. Cunningham, Historical Theology, Vol. II, p. 46).

N. H. Snaith goes so far as to deny to righteousness any place as a condition of salvation: "The fact of the matter is that God does not require righteousness at all, in any shape or shadow, as a condition of salvation. He requires faith, ...Righteousness is a result of salvation, and not a condition of it" (The Distinctive Ideas of the Old Testament, p. 164.) Again he declares: "To assume ithat ethical righteousness whether actual, imputed; or imparted (infused). is a necessary condition of salvation, is a travesty of Paul's teaching"' (p.17I).

On the other hand, Taylor sums up the position thus: "When, however, we come to the Pauline belief that justification is grounded in the atoning work of Christ, we reach a stone of stumbling, and for some theologians, a rock of offence. ... Our investigation has shown that the inner meaning of justification throws a strong light upon the poverty of our soteriological beliefs, and reveals the need for a doctrine of the Cross which provides an adequate hasis for the justifying act of God"' (p. 74, op. cit.).

In the nineteenth century Hodge asserted: "Whenever the ground of our justification is affirmatively stated, it is declared to be the obedience, the death, the blood or work of Christ" (C. Hodge, Romans. New edition, Ferdmans, 1953, p. 85). Can such an assertion be maintained today? An answer to this question is being sought by an examination of the evidence in falatians and Romans for the ground of justification.

\section{Tyndale House.}

Cambridge.

B. G. FELCE.

\section{MORE UNPUBLISAHD FYMNS BY CRARLES WESLEY}

In the lirsi issue of the Bulletin (p. 8) it was mentioned that there were numerous unpublished hymns by Charles Wesley in five manuscript volumes of liymns on the Gospels and the Book of Acts. Investigation of another sourte has resultes in further discoveries.

There ree in the possession of Richmond College, Surrey, two books containing a number of hymns in Charles Wesley's inand; one of these is afp:arents is notebnok which accompanied the poet on his travels, containing several unlinished hymns, and the other consists of interleaved pages of minuscript and leaves from early printed Wesley hymn-books. (A particularly interestins feature of the latter is that it contains, in what is plainly Charles Wesley's hand, a version. of Henry More's hymn on the coming of the Holy Spirit generally attributed to John Wesley). The two hotiks contain sixty-eight hymns or fragments of hymns which do not appear in the Poetical Works, and some of them are of considerable merit. This is the first stanza of a hymn entitled "Epinicion":

Praise to the Wonder, working GOD,

Proclaim his glorious Praise abroad,

Let Earth his Arm unshortned sing,

Let Earth rejoice, the Lord is King !

Or'e all his furious Foes $\mathrm{He}$ reigns,

And holds the Powers of Hell in Chains. 